\title{
Collaborative Governance dalam Pengelolaan Ruang Terbuka Hijau Publik (RTHP) di Kota Yogyakarta
}

\author{
Febriyanti Novita Suratman ${ }^{1)}$ Awang Darumurti ${ }^{2)}$ \\ ${ }^{1,2}$ Program Studi Ilmu Pemerintahan, Universitas Muhammadiyah Yogyakarta. Indonesia. \\ * Korespondensi Penulis. E-mail: awang.darumurti@yahoo.com
}

\begin{abstract}
Abstrak: Collaborative Governance merupakan kerjasama antar Stakeholder yang memuat pihak pemerintah, swasta dan masyarakat. Kota Yogyakarta sangat memerlukan kerjasama antar Stakeholder untuk dapat mewujudkan pembangunan dan pengelolaan RTHP, mengingat luas wilayah Kota Yogyakarta yang relatif kecil dan pentingnya keberadaan RTHP yang bukan hanya menjadi penghijauan tetapi juga untuk menjaga keseimbangan di lingkungan perkotaan. Oleh karena itu, DLH Kota Yogyakarta yang menjadi pemeran kunci dalam pengelolaan RTHP mengajak instansi lain seperti Dinas Komunikasi, Informasi dan Persandian Kota Yogyakarta dan pihak swasta seperti CV Sarana Mega Konstruksi, serta mengajak masyarakat sekitar untuk bekerjasama dalam membangun dan mengelolaan RTHP. Penelitian ini bertujuan untuk mengetahui bagaimana proses Collaborative Governance yang selama ini dijalin antar Stakeholder untuk mewujudkan pengelolaan RTHP yang baik. Jenis penelitian yang digunakan yaitu kualitatif dengan pendekatan deskriptif. Teknik pengumpulan data yang digunakan dalam penelitian ini yaitu wawancara dan dokumentasi. Penelitian ini menggunakan hasil analisa dari teori yang digunakan. Hasil penelitian yakni Collaborative Governance melalui 4 proses yakni adanya tahapan assesment, tahapan initiation, tahapan deliberation dan tahapam implementation.
\end{abstract}

Kata kunci: Collaborative Governance, Ruang Terbuka Hijau Publik (RTHP)

\begin{abstract}
Collaborative Governance is a collaboration between stakeholders that includes the government, the private sector, and the community. The city of Yogyakarta needs cooperation between stakeholders to be able to realize the development and management of the RTHP, given the relatively small area of the city of Yogyakarta and the importance of the existence of the RTHP which is not only reforestation but also to maintain balance in the urban environment. Therefore, DLH Yogyakarta, which is a key player in the management of the RTHP, invites other agencies such as the Yogyakarta City Communication, Information and Encryption Service and private parties such as CV Sarana Mega Konstruksi, and invites the surrounding community to cooperate in building and managing the RTHP. This study aims to find out how the collaborative governance process has been woven between stakeholders to realize good RTHP management. The type of research used is qualitative with a descriptive approach. Data collection techniques used in this study are interviews and documentation. This study uses the results of the analysis of the theory used. The results of the research are Collaborative Governance through 4 processes, namely the assessment stage, initiation stage, deliberation stage, and implementation stage.
\end{abstract}

Keywords: Collaborative Governance, Public Green Open Space

Article History:

Received : 2021-01-24

Revised : 2021-02-19

Accepted : 2021-03-17

\section{PENDAHULUAN}

Kota sebagai pusat perkembangan, pembentukan, perubahan, pelayanan dan sebagai pusat untuk kegiatan ekonomi, sosial budaya, politik, teknologi dan sebagainya, dan juga harus memenuhi fasilitas untuk penduduknya (Jamaludin, 2015). Perencanaan pembangunan kota adalah salah satu cara mengenal sebuah kota sehingga dapat menentukan wajah kota dan mengimplementasikannya secara bertahap dengan prioritas tertentu sehingga dapat mencapai sebuah nilai atau tujuan tertentu dibidang fisik, sosial dan ekonomi di masa depan (Hariyono, 2017). Sebuah kota memiliki luas lahan yang terbatas, namun permintaan sarana dan prasarana dari penduduk membuat semakin sempitnya lahan untuk ruang terbuka hijau, contohnya seperti 
pemukiman, lahan untuk gedung yang akan menunjang berbagai aktifitas, lahan untuk lalu lintas transportasi serta pembangunan lainnya yang akan terus menerus berkembang. Berbagai hal tersebut dapat terjadi karena semakin meningkatnya jumlah penduduk yang ada di kota, serta banyaknya kegiatan, kebutuhan dan permintaan dari masyarakat kota. Sehingga, dalam pelaksanaan pembangunan yang berkelanjutan ini, akan memberikan konsekuensi terhadap penyusutan Ruang Terbuka Hijau (RTH).

RTH merupakan salah satu bagian terpenting dari struktur kota yang memiliki fungsi sebagai penunjang ekologis yang juga diperuntukkan sebagai penambah ruang terbuka, sebagai pendukung nilai kualitas lingkungan dan budaya suatu kawasan, serta menghindari kerusakan di perkotaan seperti terjadinya polusi udara (Rosawatiningsih, 2019). Pemerintah sudah memberikan kebijakan bahwa sumber daya alam yang ada dapat dimanfaatkan untuk modal pembangunan demi mencapai sebuah kesejahteraan bangsa dan dalam waktu yang tidak ditentukan. Namun, tata kelola perkotaan di Indonesia masih harus mendapat perhatian penuh karena yang terjadi di lapangan menunjukkan bahwa pembangunan yang dilakukan kurang memperhatikan konsep tersebut, sehingga sumber daya alam yang tersedia menjadi rusak dan menyebabkan berbagai bencana (Andriani, 2019). Berkaitan dengan pembangunan berkelanjutan dan lingkungan hidup, maka dalam setiap pelaksanaannya diperlukan adanya perencanaan tata ruang bagi wilayah perkotaan. Pemerintah mengeluarkan peraturan yang tertuang dalam Undang-Undang Nomor 26 Tahun 2007 tentang Penataan Ruang yang dapat menjadi acuan dasar bagi setiap wilayah untuk membangun RTH, sehingga tercipta wilayah yang bersih, indah, nyaman dan sehat. Setiap wilayah kota harus menyediakan RTH sebesar $30 \%$ dari luas wilayahnya, dengan proporsi 20\% RTH Publik (RTHP) yang bersifat terbuka untuk umum, serta 10\% RTH Privat (Astriani, 2015). Pembuatan RTH dapat dipicu oleh beberapa indikator seperti jumlah penduduk, kebutuhan air bersih, serta kebutuhan oksigen, karena hadirnya RTH ini dapat meningkatkan produksi oksigen dan menyerap karbondioksida.

RTHP sangat dibutuhkan diranah ruang lingkup publik yang memiliki banyak manfaat, khususnya dalam masalah tata ruang kota (Haryanto, 2019). Sebagai contoh, Pemerintah Kota Yogyakarta mulai menggerakkan masyarakat di setiap kampung untuk melakukan penghijauan dengan cara menanam tanaman di bantaran sungai serta mengajak masyarakat untuk samasama merawat tanaman tersebut (Budiman et al., 2014). Minimnya lahan untuk pembangunan RTHP di Kota Yogyakarta membuat pemerintah harus lebih pintar memanfaatkan sisa lahan yang ada, contohnya adalah pembuatan RTHP yang memanfaatkan lokasi di tepian trotoar untuk penghijauan tanpa mengilangkan fungsi trotoar tersebut. Pemerintah juga melakukan kerjasama yang dilakukan oleh Dinas Lingkungan Hidup Kota Yogyakarta mulai tahun 20082012. Stakeholder yang terlibat yaitu pelaku ekonomi di sepanjang jalan yang ada perindang jalan misalnya di Jalan Sudirman atau Jalan Urip Sumoarjo yang dimana semua toko yang ada di sepanjang jalan harus menyumbangkan tanaman pergola atau taman yang merambat. Kemudian, yang ada di sepanjang Jalan Abu Bakar Ali adalah sumbangan dari Bank BNI (Andhini, 2017).

Dalam proses pengelolaan RTHP tersebut pihak Dinas Lingkungan Hidup Kota Yogyakarta mengajak beberapa instansi seperti Dinas Tata Ruang, Dinas Pekerjaan Umum, Dinas Pertanahan. Dinas Lingkungan Hidup Kota Yogyakarta juga mengajak kerjasama Stakeholder dari pihak swasta dan masyarakat. Pihak swasta yang terlibat dari CV Sarana Mega 
Konstruksi yang berperan sebagai kontraktor yang membantu dalam pemeliharaan RTH di perkotaan seperti pemangkasan pohon. Masyarakat berperan sebagai aktor yang memberi informasi kepada pihak pemerintah melalui Lembaga Pemberdayaan Masyarakat Kelurahan (LPMK) jika ada lahan kosong atau akan dijual, kemudian mengajukan permintaan agar dibuatkan RTHP dilingkungan mereka. Oleh karena itu, diperlukan kerjasama dan hubungan yang baik antar Stakeholder, sehingga setiap tujuan dan kegiatan dapat berjalan dengan baik sesuai dengan perencanaan. Kerjasama-kerjasama itulah yang biasa disebut sebagai Collaborative Governance, yang berarti sebuah penataan pemerintahan yang dimana badan publik melibatkan secara langsung berbagai pemangku kepentingan (diluar pemerintahan terlait) dalam proses pengambilan keputusan kolektif yang bersifat formal, berorientasi pada konsensus dan musyawarah yang bertujuan untuk membuat suatu kebijakan atau program publik (Ansell \& Gash, 2007).

Data dari web resmi Dinas Lingkungan Hidup Kota Yogyakarta pada tahun 2020 menunjukkan bahwa ada 6 lokasi RTHP yang dibangun, dimana 4 lokasi RTHP dalam kondisi terpelihara dan 2 lokasi dalam penyempurnaan RTHP dengan penambahan elemen tanaman. Data kegiatan pertamanan dan perindangan jalan yaitu terdapat 18.882 pohon perindang jalan jalur hijau yang kondisinya terpelihara, 400 titik penanaman pohon, $66.906 \mathrm{~m} 2$ taman kota yang terpelihara, dan 1 lokasi taman kota yang direnovasi dengan penambahan elemen taman dekoratif. Semua pengelolaan RTHP tersebut membutuhkan alokasi dana sebesar Rp 10.206.768. Dengan pencapaian tersebut dan mengingat luas wilayah Kota Yogyakarta yang kecil yaitu hanya 32,5 km2 atau 1,025\% dari luas wilayah DIY (BPS, 2020), serta pentingnya keberadaan RTHP yang bukan hanya menjadi penghijauan tetapi juga untuk menjaga keseimbangan di lingkungan perkotaan, maka memunculkan pertanyaan bagaimana semua elemen Stakeholder di Kota Yogyakarta bekerjasama dalam mewujudkan hadirnya RTHP dan tahapan apa saja yang dilakukan dalam mewujudkan RTHP tanpa mengganggu pemukiman warga yang padat.

Jika pada penelitian terdahulu yang membahas terkait Collaborative Governance, banyak sekali digunakan teori milik Ansell dan Gash, seperti penelitian oleh (Tresiana \& Duadji, 2017) yang membahas Kolaboratif Pengelolaan Pariwisata Teluk Kiluan, dan pada tahun 2018 membahas terkait Kota Layak Anak Berbasis Collaborative Governance (Duadji \& Tresiana, 2018). Penelitian dengan teori yang sama dilakukan oleh (Ulfa, 2018) dengan penelitian Collaborative Governance dalam Penyediaan Ruang Terbuka Hijau (RTH) Taman Kota di Surabaya, (Amelia, 2018) yang membahas Collaborative Governance dan Pengelolaan Lingkungan Hidup di Kawasan Pertambangan, (Arianti \& Satlisa, 2018) yang membahas Collaborative Governance Dalam Pengembangan Konservasi Mangrove Baros di Desa Tirtohargo Kecamatan Kretek, serta penelitian oleh (Parameshwari et al., 2020) yang membahas masalah Collaborative Governance dalam Manajemen Tata Ruang di Cafe Sawah Pujon Kidul Kabupaten Malang. Maka penelitian ini dilakukan dengan menggunakan beberapa indikator dari (Morse \& Stephen, 2012) untuk menilai dan menganalisis bagaimana proses Collaborative Governance di Kota Yogyakarta khususnya pada pembangunan dan pengelolaan RTHP dapat terjadi. Indikator atau tahapan tersebut meliputi: 
Tabel 1. Indikator Penelitian

\begin{tabular}{|c|c|c|}
\hline Konsep & Variabel & Indikator \\
\hline \multirow{4}{*}{ Collaborative Governance } & Assesment & $\begin{array}{l}\text { - Perlunya collaborative governance } \\
\text { - Mengidentifikasi Stakeholder } \\
\text { - Mengidentifikasi pemeran kunci }\end{array}$ \\
\hline & Initiation & $\begin{array}{l}\text { - Mengidentifikasi sumber daya } \\
\text { - Mempertemukan pemangku } \\
\text { kepentingan } \\
\text { - Mendesign proses }\end{array}$ \\
\hline & Deliberation & $\begin{array}{l}\text { - Membangun aturan dasar } \\
\text { - Musyawarah dan dialog } \\
\text { - Mencapai kesepakatan kolaboratif }\end{array}$ \\
\hline & Implementation & $\begin{array}{l}\text { - Adanya pembagian tugas } \\
\text { - Mengevaluasi hasil }\end{array}$ \\
\hline
\end{tabular}

METODE PENELITIAN

Penelitian ini menggunakan metode kualitatif dengan pendekatan deskriptif. Penelitian deskriptif menjelaskan suatu keadaan dengan sebenarnya dan penulis tidak memanupulasi data yang diperoleh (Sudaryono, 2017). Data-data pada penelitian ini diperoleh dari hasil wawancara dan dokumentasi. Wawancara dilakukan dengan Stakeholder terkait, seperti dari Bidang RTHP (seksi pengelolaan RTHP, seksi pertamanan dan perindangan jalan) Kota Yogyakarta, dari pihak swasta yaitu CV Sarana Mega Konstruksi, serta dari masyarakat. Sedangkan untuk dokumentasi diartikan dengan informasi dengan catatan baik yang berasal dari sebuah intansi lembaga maupun perorangan mengenai peristiwa atau kegiatan dalam keadaan sosial yang terkait dengan fokus penelitian, yang dimana sumber dokumen tersebut berguna dan membantu dalam penelitian kualitatif (Yusuf, 2014). Dokumentasi yang digunakan berupa laporan, foto, tabel, grafik dan lainnya.

\section{HASIL DAN PEMBAHASAN}

Untuk mengetahui lebih rinci mengenai kerjasama yang dilakukan antara pihak pemerintah, pihak swasta dan masyarakat dalam mewujudkan hadirnya RTHP di Kota Yogyakarta, maka dilakukan penelitian yang berfokus terhadap proses Collaborative Governance, dimana proses ini merupakan elemen penting dalam keberhasilan sebuah kerjasama, untuk menganalisis permasalahan tersebut peneliti menggunakan teori Ricardo S. Morse dan John B. Stephen (2012) yang berisikan empat tahapan yang terdiri atas, assesment, initiation, deliberation dan juga implementation. Penjelasan terkait setiap tahapan tersebut yaitu sebagai berikut:

\section{Tahapan Assesment}

Tahap pertama dari Collaborative Governance adalah tahap assesment atau tahap penilaian untuk mengetahui apakah suatu kerjasama antar Stakeholder itu diperlukan atau 
tidak. Ada beberapa indikator pada tahapan ini, yaitu sebagai berikut:

\section{a. Perlunya Collaborative Governance}

Sebelum Collaborative Governance dilaksanakan, dibutuhkan suatu analisa awal untuk menentukan perlu atau tidaknya Collaborative Governance dalam menyelesaikan permasalahan yang dihadapi oleh suatu instansi. Indikator ini juga sebagai wadah untuk memaksimalkan sumber daya yang ada, sehingga sumber daya tersebut dapat teralokasi dengan baik guna menyelesaikan permasalahan yang terjadi yang memerlukan bantuan atau kerjasama dengan pihak lain.

Di Kota Yogyakarta, pengelolaan RTHP tidak dapat dilaksanakan oleh satu instansi saja, karena ada bagian kerja yang tidak dapat dilakukan oleh DLH Kota Yogyakarta, sehingga memerlukan kerjasama dengan instansi atau pihak lain. Sebagai contoh, kawasan Malioboro memerlukan Collaborative Governance, mengingat Malioboro merupakan ikon Kota Yogyakarta yang tidak pernah sepi dari wisatawan dan perlu dijaga kehijauannya. Kawasan Malioboro melibatkan berbagai instansi yang berasal dari pemerintah, dan di bantu oleh pihak swasta seperti pemilik mall, toko dan hotel (pemilik modal) serta di bantu oleh masyarakat untuk pemeliharaan di area sekitar kawasan malioboro. Collaborative Governance juga diperlukan di area pemukiman warga, misalnya di Kecamatan Umbulharjo, karena kecamatan ini memiliki RTHP Taman Kelurahan yang cukup banyak. Kerjasama dilakukan dengan mengajak pihak swasta sebagai pihak yang membangun RTHP sesuai rancangan yang disepakati dengan dengan dibantu masyarakat di area pemukiman tersebut. Hal tersebut sesuai dengan hasil wawancara dengan Ibu Rina Ayati Nugraha selaku Kepala Seksi Pengelolaan RTHP Kota Yogyakarta (14 Desember 2020):

"Collaborative atau kerjasama dengan Stakeholder sangat diperlukan untuk pengelolaan RTHP, apalagi tahap yang dilakukan dari perencanaan, pembangunan, hingga selesainya pembangunan sangat memerlukan banyak stakeholde, dan saat ini pihak DLH sedang gencar untuk menambahkan RTHP di daerah pemukiman karena saat ini RTHP Kota Yogyakarta belum sampai memenuhi $20 \%$ dari luasan kota, untuk sekarang baru mencapai $8 \%$ dari luasan kota."

Kerjasama lain di Kecamatan Umbulharjo (RTHP Sorosutan, RTHP Giwangan dan RTHP Pandeyan), dimana DLH Kota Yogyakarta bekerjasama dengan Dinas Komunikasi, Informasi dan Persandian Kota Yogyakarta untuk menyediakan fasilitas free wifi bagi masyarakat di lingkungan pemukiman terutama untuk anak-anak yang sedang melakukan sekolah secara daring. Dilakukan pula penghijauan di Jalan Kenari, Kelurahan Semaki, dimana sepanjang jalan trotoar ditanami elemen tanaman dari DLH dan pemeliharaannya dibantu oleh pihak swasta yaitu para pemilik toko yang berada di sepanjang jalan tersebut. Kerjasama dengan Dinas Komunikasi, Informatika dan Persandian Kota Yogyakarta juga dilakukan di Kelurahan Pandeyan (RTHP Taman Flamboyan dan RTHP Gajahwong Education Park) dengan membantu memberikan fasilitas perangkat mini cinema yang diharapkan dapat mengedukasi masyarakat di bantaran sungai, sekaligus memperkuat fungsi RTHP. 


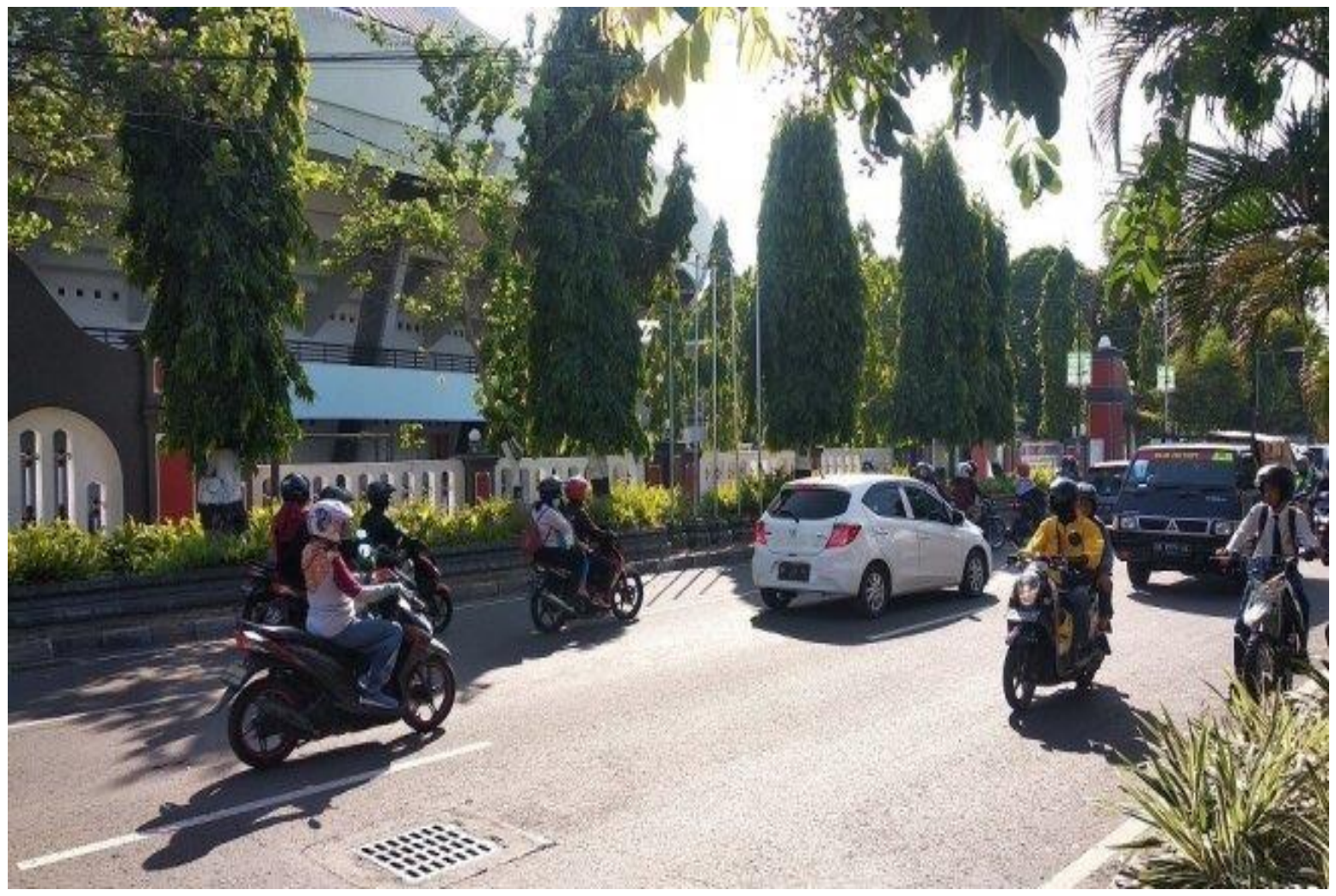

Gambar 1. Suasana Jalan Kenari dan Pemandangan Penghijauan Sumber: suarajogja.id

Berdasarkan contoh di atas, dapat disimpulkan bahwa Collaborative Governance sangat di perlukan dalam pengelolaan RTHP di Kota Yogyakarta guna menyelesaikan berbagai permasalahan yang ada, misalnya permasalahan pembangunan dan pemeliharaan RTHP di kawasan pemukiman warga dan daerah padat wisatawan.

\section{b. Mengidentifikasi Stakeholder}

Indikator ini digunakan untuk penentuan siapa saja pemangku kepentingan yang akan diajak untuk bekerjasama. Pada dasarnya Collaborative Governance memerlukan 3 stakeholder, yaitu dari pihak pemerintah, swasta dan masyarakat. Proses ini berguna agar kerjasama yang dijalankan dapat terlaksana dengan baik, serta untuk menentukan pembagian tugas masing-masing stakeholder dalam menjalankan kerjasama yang terjalin. Dalam hal ini, DLH Kota Yogyakarta menggandeng masyarakat yang berperan dalam pemeliharaan dan membantu pemerintah dalam mewujudkan hadirnya RTHP dengan proporsi $20 \%$ dengan mengajukan proposal pembuatan RTHP di lingkungan kelurahan, serta pihak swasta sebagai aktor yang membangun bangunan RTHP yang sesuai rancangan dan dibantu dengan pihak swasta lain seperti pemilik toko untuk pemeliharaan. Seperti yang disampaikan oleh Bapak Pramu Haryanto selaku Kepala Seksi Pertamanan dan Perindangan (15 Desember 2020):

"Dalam seksi saya sendiri itu kan memerlukan banyak Stakeholder, karena seksi saya mengelola RTHP yang berada di ruas jalan Kota Yogyakarta oleh karena itu selain staff lapangan yang direkrut melalui website saya juga membutuhkan dari pihak swasta untuk diajak bekerjasama dalam memelihara RTHP yang tersebar di berbagai ruas jalanan 


\section{Kota Yogyakarta."}

Pihak CV Sarana Mega Konstruksi merupakan pihak swasta yang telah melakukan kontrak kerja dengan DLH Kota Yogyakarta untuk membantu dalam pemeliharaan tanaman yang berada di perkotaan. Menurut Bapak Supramana sebagai Kepala CV Sarana Mega Konstruksi (17 Februari 2021):

"Satu-satunya pihak swasta yang tergabung dalam kerjasama pemeliharaan RTHP hanya CV Sarana Mega Konstruksi yang mampu menyanggupi pekerjaan yang ditawarkan oleh pihak DLH Kota Yogyakarta sejak tahun 2019 karena tidak ada kontraktor lain yang mau mengambil resiko pekerjaan ini."

Masyarakat berperan dari awal proses pembangunan RTHP hingga pembangunan selesai sekaligus memelihara RTHP tersebut, hal ini dilakukan agar RTHP dapat terealisasikan dan difungsikan sesuai kebutuhan masyarakat. Pernyataan tersebut dibenarkan oleh masyarakat di salah satu kelurahan yaitu Bapak Slamet Widayat selaku Ketua RT 07 Kelurahan Kricak:

"Dalam pengelolaan RTHP ini baik pihak pemerintah maupun pihak masyarakat sangat aktif dalam melakukan komunikasi untuk pengelolaan RTHP dari proses awal sampai akhir hingga sampai di tahap pemeliharaan."

Sebagai contoh, pengelolaan sempadan sungai Taman Flamboyan dimana awalnya berupa lahan kosong yang berada di tepian sungai dan kondisi tidak terawat serta menjadi tumpukan sampah. Masyarakat sekitar berinisiatif untuk mengelola lahan tersebut agar dijadikan tempat yang memiliki fungsi bagi masyarakat sekitar, dan akhirnya dibuatkan RTHP oleh pemerintah. Dengan demikian, Pemerintah Kota Yogyakarta dalam hal ini Dinas Lingkungan Hidup Kota Yogyakarta berupaya untuk menggandeng semua Stakeholder yang ada guna mewujudkan RTHP yang maksimal di Kota Yogyakarta.

\section{c. Mengidentifikasi Pemeran Kunci}

Dalam pengelolaan RTHP baik yang berada di pemukiman kecamatan dan kelurahan atau yang berada di tengah kota seperti penghijauan, dipegang oleh Dinas Lingkungan Hidup Yogyakarta yang bertugas untuk mengkoordinasi seluruh stakeholder yang terlibat dalam kerjasama untuk bersama-sama mengelola RTHP. Proses pembangunan dan pengelolaan RTHP dijalankan oleh dua seksi, pertama yaitu Seksi Pengelolaan RTHP bertugas mengkoordinasikan pembangunan dan pemeliharaan yang berada di pemukiman masyarakat (karena pembangunan RTHP untuk area sosial difokuskan pada wilayah tersebut).

Hal tersebut dibenarkan oleh:

"Pihak DLH merupakan pihak penyedia yang memiliki tanggungjawab penuh atas keberlangsungan hadirnya RTHP juga memiliki peran sebagai wadah untuk masyarakat menyampaikan usulan pembangunan atau pengelolaan RTHP." (Bapak Slamet Widayat selaku Ketua RT 07 Kelurahan Kricak, 7 Januari 2021)

"Memang pemeran kunci dalam pengelolaan RTHP dipegang oleh DLH Kota Yogyakarta, karena semua instruksi berasal dari pihak DLH yang menjadi acuan dalam melakukan 
pekerjaan lapangan.” (Bapak Supramana, Kepala CV Sarana Mega Konstruksi, 17 Februari 2021)

Kedua, yaitu Seksi Pertamanan dan Perindang Jalan berfungsi untuk menciptakan ruas jalan yang asri dengan penanaman elemen tanaman di tepian jalan dan dipantau setiap hari. Hal ini sesuai dengan yang dipaparkan oleh Bapak Pramu Haryanto Kepala Seksi Pertamanan dan Perindang Jalan (15 Desember 2020):

"Pemeliharaan RTHP yang tersebar diberbagai ruas jalanan Kota Yogyakarta terpelihara setiap hari karena dari DLH telah merekrut 140 staff yang akan keliling kota untuk memonitoring elemen tanaman. Staff lapangan milik DLH melakukan penyiraman dan pemotongan guna merapikan tanaman tanaman yang berada di ruas jalan."

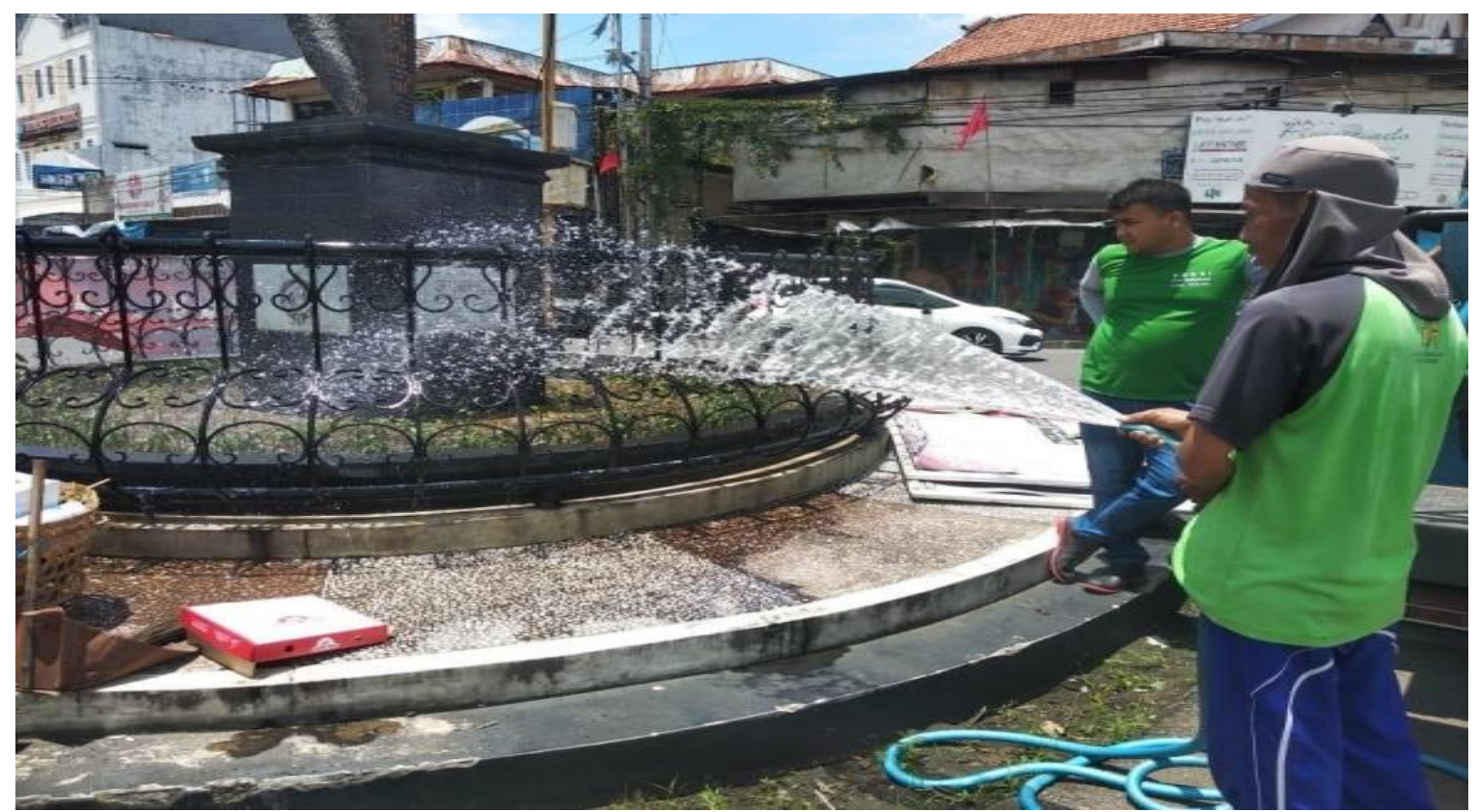

Gambar 2. Staff Lapangan DLH Melakukan Pemeliharaan Sumber: Dinas Lingkungan Hidup Kota Yogyakarta

\section{Tahapan Initiation}

Tahapan selanjutnya yaitu initiation atau permulaan, tahapan ini dilakukan untuk mengetahui keadaan dan kondisi yang akan dilakukan. Ada beberapa indikator pada tahap ini, yaitu:

\section{a. Mengidentifikasi Sumber Daya}

Sumber daya menjadi hal penting dalam membantu keberhasilan pelaksanaan Collaborative Governance, oleh karena itu perlu dilakukan persiapan dan penyediaan sumber daya yang memadai untuk membangun dan mengelola RTHP. Pada kasus ini, di dalam proses pengelolaan RTHP Kota Yogyakarta, baik di pemukiman masyarakat atau di tepian jalan untuk penghijauan, sumber daya seperti infrastruksur, sumber daya manusia serta pendanaan dapat dikatakan cukup memadai. Hal ini di sampaikan oleh Bapak Pramu Haryano sebagai Kepala Seksi Pertamanan dan Perindang Jalan (15 Desember 2020):

"Sumber daya yang ada baik dari sumber daya manusia, pendanaan dan sarana 
prasarana pada saat ini cukup memadai untuk mengelola berbagai tanaman yang tersebar di berbagai ruas jalan yang berada di Kota Yogyakarta. Untuk seksi pertamanan dan perindang jalan menurunkan 140 staff lapangan yang bertugas sebagai pemelihara yang beroperasi setiap hari guna memelihara tanaman yang di rekrut melalui website DLH Kota Yogyakarta. Untuk pendanaan semua berasal dari APBD."

Tabel 2. Sarana Prasarana Pengelolaan RTHP dari DLH Kota Yogyakarta

\begin{tabular}{|l|l|l|}
\hline No. & Sarana dan Prasarana & Jumlah \\
\hline 1. & Dump truck & 2 Unit \\
\hline 2. & Sky truck/prunning & 1 Unit \\
\hline 3. & Truk tangki penyiram & 9 Unit \\
\hline 4. & Motor roda tiga & 6 Unit \\
\hline 5. & Gergaji mesin & 9 Unit \\
\hline 6. & Mesin pemotong rumput & 8 Unit \\
\hline 7. & Mesin pompa air & 10 Unit \\
\hline 8. & Mobil / pick up & 2 Unit \\
\hline
\end{tabular}

Sumber: (Dinas Lingkungan Hidup Kota Yogyakarta, 2017)

Sumber daya manusia berasal dari masyarakat dan juga para pemilik toko atau usaha, yang mana disenjang jalan atau depan toko mereka ditanami elemen tanaman dari DLH Kota Yogyakarta. Seperti di Jalan Margo Utomo yang merupakan kawasan bisnis yang banyak terdapat toko, hotel serta perkantora. Semua elemen masyarkat ikut serta menjaga dan memelihara RTHP di kawasan sekitar mereka. Sumber daya lain juga berasal dari pihak swasta yang sudah bekerja sama dengan DLH yaitu CV Sarana Mega Konstruksi. Seperti pernyataan dari Bapak Supramana, Kepala CV Sarana Mega Konstruksi (17 Februari 2021):

"Fasilitas yang tersedia untuk kerjasama ini dari pihak saya sendiri adalah adanya 15 tenaga kerja dan fasilitas sarana prasarana untuk kerja dilapangan karena semua sarana prasana dan alat pelindung diri (APD) semua berasal dari pihak swasta sendiri. Pendanaan semuanya penuh dari DLH, tetapi jika ada terjadi resiko dilapangan kepada pekerja itu sudah tanggungjawab CV sendiri."

Tabel 3. Sarana Prasarana Pengelolaan RTHP dari CV Sarana Mega Konstruksi

\begin{tabular}{|c|l|l|}
\hline No. & Sarana dan Prasarana & Jumlah \\
\hline 1. & Truk & 2 Unit \\
\hline 2. & Alat pangkas & 3 Unit \\
\hline 3. & Tali tambang $50 \mathrm{~m}$ & 2 Unit \\
\hline
\end{tabular}

\section{b. Mempertemukan Pemangku Kepentingan}

Indikator ini bertujuan agar semua Stakeholder ikut serta dalam pelaksanan Collaborative Governance, sekaligus sebagai media untuk menyusun rencana dan berkoordinasi guna mencapai sasaran atau tujuan. Pada pengelolaan RTHP Kota Yogyakarta, pihak swasta dikontrak melalui tender yang dipromosikan melalui Layanan Pengadaan Secara Elektronik (LPSE). Apabila pihak swasta tersebut memenangkan tender, maka akan direkrut untuk menjalin kerjasama. Awal mula kontrak kerja disampaikan oleh Bapak Supramana (17 Februari 2021). 
"CV Sarana Mega Konstruksi memenangkan tender tersebut dan mulai tergabung dengan pihak DLH Kota Yogyakarta sejak tahun 2019 dan masih lanjut untuk di tahun 2020 untuk pengelolaan RTHP yang berada di perkotaan untuk perindang jalan."

Pertemuan juga dilakukan dengan masyarakat melalui tokoh masyarakat seperti camat, lurah, ketua RT/RW dll. Proses pertemuan diawali dengan mengajukan proposal pembangunan RTHP dari masyarakat yang diwakilkan oleh tokoh masyarakat kepada walikota. Kemudian, jika proposal diterima, DLH akan melakukan pertemuan bersama masyarakat untuk membahas perencanaan program tersebut. Seperti pernyataan berikut ini:

"Ketika pengajuan proposal dari masyarakat yang diajukan melalui LPMK dapat dilaksanakan pembangunan RTHP, maka kemudian pihak pemerintah akan melakukan pertemuan untuk merundingkan bagaimana pembangunan yang akan dilaksanakan." (Rina Aryati Nugraha, Kepala Seksi Pengelolaan RTHP, 14 Desember 2020)

"Pada saat proposal sudah diterima bahwa akan dilakukannya pembangunan RTHP maka langkah pertama yang di ambil oleh pihak DLH adalah dengan mengadakan sosialisasi guna mengambil usulan dari masyarakat." (Slamet Widayat, Ketua RT 07 Kelurahan Kricak, 7 Januari 2021)

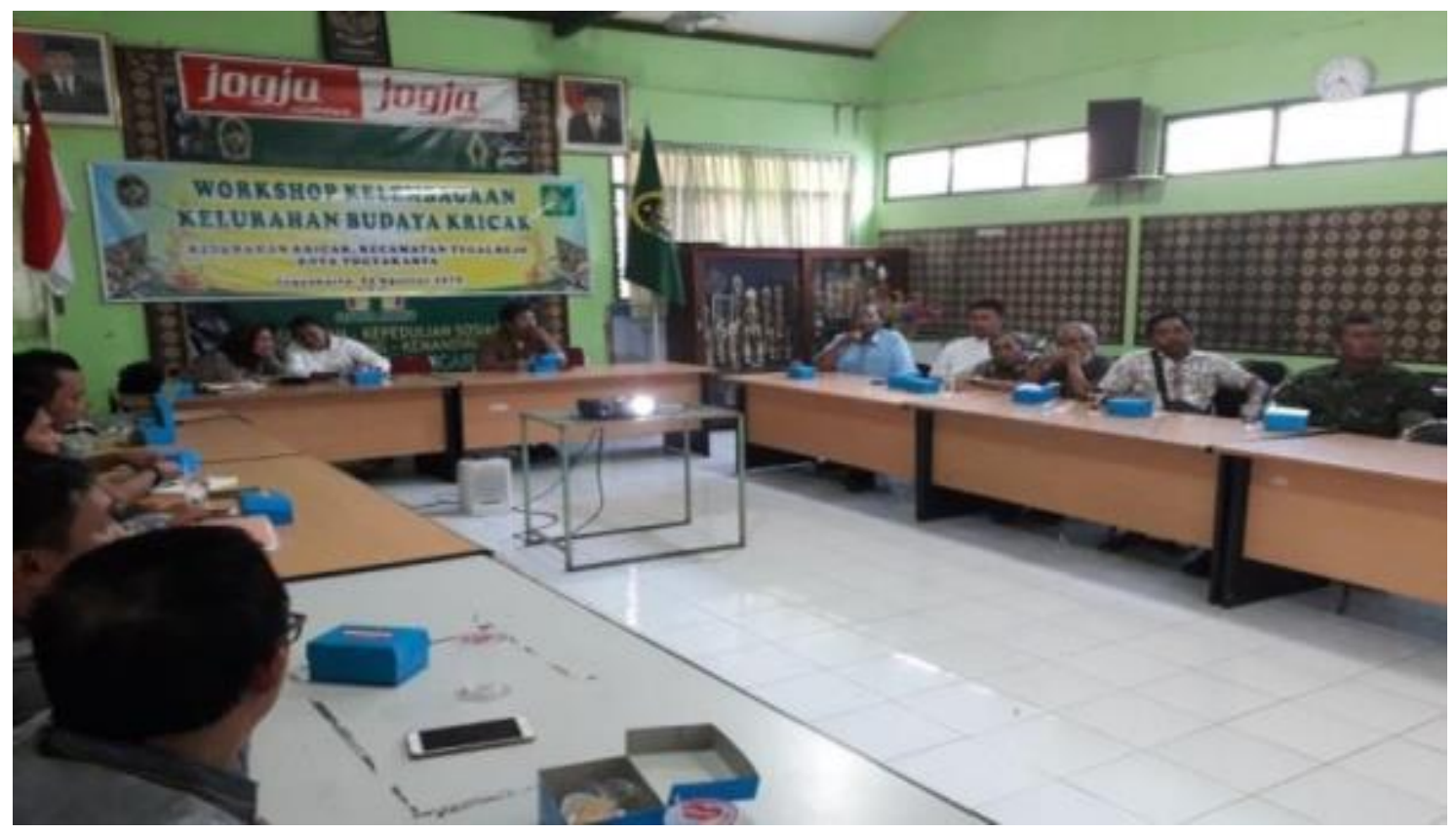


Gambar 3. Sosialisasi RTHP oleh DLH kepada Masyarakat Kelurahan Kricak

Sumber: Dinas Lingkungan Hidup Kota Yogyakarta

Contoh lain pada kawasan Malioboro, juga dilakukan pertemuan dan koordinasi antar Stakeholder yaitu pemerintah, swasta dan masyarakat di kawasan Malioboro. Pertemuan dan kordinasi dilakukan antara SKPD beserta LPKKM, kelurahan dan kecamatan serta UPT Malioboro. Kemudian hasil dari pertemuan disampaikan oleh UPT Malioboro kepada paguyuban di wilayan Malioboro, sehingga mempermudah penyampaian rencana atau kebijakan.

\section{c. Mendesign Proses}

Design proses merupakan penyusunan rencana kerja yang dilakukan oleh seluruh Stakeholder. Proses ini penting dilakukan untuk menyusun rencana kerja yang disetujui oleh seluruh Stakeholder, sehingga masing-masing Stakeholder memiliki andil dan memiliki rasa tanggungjawab dalam menjalankan tugas mereka. Hasil dari proses ini yaitu Standart Operating Procedure (SOP) untuk menjalankan Collaborative Governance. Namun, pada proses pengelolaan RTHP yang dilakukan oleh DLH Kota Yogyakarta tidak melakukan pembuatan SOP kerjasama sebagai landasan dalam menjalankan tugas. Stakeholder hanya mendapat arahan yang didapatkan secara lisan dari pihak DLH Kota Yogyakarta. Seperti pernyataan berikut:

"Dalam menjalankan kontrak kerja dengan pihak DLH tidak adanya SOP, akan tetapi kedua belah pihak selalu menjalin komunikasi untuk melakukan tugas dan sudah melakukan kontrak kerja sehingga memiliki target kerja dalam satu tahun yang harus dicapai.” (Supramana, Kepala CV Sarana Mega Konstruksi, 17 Februari 2021)

"Kita (DLH dan CV Sarana Mega Konstruksi) hanya menjalani komunikasi 2 arah dalam mengerjakan sesuatu dan tanpa adanya SOP. Untuk ke masyarakat diberikan arahan apabila daerah tersebut memerlukan sterilisasi karena daerah tersebut berbahaya jika dilalui, selain arahan juga diberi dengan rambu-rambu untuk peringatan." (Pramu Haryanto, Kepala Seksi Pertamanan dan Perindang Jalan, 15 Desember 2020)

SOP juga tidak dibentuk untuk masyarakat yang berada di permukiman kecamatan dan kelurahan serta RTHP sempadan sungai yang juga dibangun di area permukiman. Hal ini sesuai dengan yang disampaikan oleh Ibu Rina Aryati, Kepala Seksi Pengelolaan RTHP (14 Desember 2020):

"Untuk peraturan kepada masyarakat yang berada di wilayah permukiman antara DLH dan masyarakat hanya menjalin komunikasi 2 arah dan dilakukan dengan waktu yang intens."

Bagi masyarakat yang berada di wilayah permukiman yang telah dibangun RTHP baik yang menjadi RTHP kelurahan maupun RTHP sempadan sungai, mereka akan aktif untuk melakukan komunikasi dengan pihak pemerintah. Mereka juga dengan senang hati membantu dalam pemeliharaan RTHP. Apabila pada kurun waktu 2 sampai 3 hari staff dari DLH Kota Yogyakarta tidak melakukan pembersihan, maka masyarakat yang akan turun untuk membersihkan RTHP tersebut. 


\section{Tahapan Deliberation}

Tahapan ini dilakukan setelah semua Stakeholder memberikan komitmennya untuk bekerjasama dan menyetujui kesepakatan sebelumnya. Indikator pada tahap ini yaitu:

\section{a. Membangun Aturan Dasar}

Aturan dasar digunakan sebagai landasan bagi seluruh Stakeholder untuk menjalankan kerjasama. Adanya aturan tersebut diharapkan dapat membuat kerjasama yang dilakukan menjadi lebih jelas dan terarah. Ada beberapa aturan dasar yang digunakan untuk menjalin kerjasama antar Stakeholder dalam pengelolaan RTHP. Seperti yang disampaikan oleh Ibu Rina, Kepala Seksi Pengelolaan RTHP (14 Desember 2020):

"Dalam pengelolaan RTHP untuk saat ini kita (DLH) masih berpatokan pada aturan dasar yang termuat dalam Perwal Yogyakarta No 5 Tahun 2016."

Aturan tersebut ditujukan kepada pihak pemerintah dan masyarakat, yang mana berisikan aturan dasar bagi pihak DLH Kota Yogyakarta dan masyarakat dalam menjalankan tugas pengelolaan atau pemeliharaan RTHP. Dalam aturan dasar juga termuat prosedur bagi masyarakat untuk mengajukan permintaan pembuatan RTHP di wilayah permukiman. Untuk kerjasama dengan UPT Malioboro dijalankan dengan berdasar pada Peraturan Walikota No. 18 Tahun 2012 BAB V pasal 12 ayat 1 dan 2, terkait pendistribusian tugas. Sedangkan dengan pihak swasta yaitu CV Sarana Mega Konstruksi hanya dilakukan kesepakatan kerja untuk mencapai target yang ingin dicapai. Hal ini sesuai dengan pernyataan berikut:

"Antara pihak DLH dan CV Sarana Mega Konstruksi tidak ada peraturan yang terlalu mengikat dalam menjalankan kerjasama, yang penting tugasnya dalam setahun terselesaikan." (Pramu Haryanto, Kepala Seksi Pertamanan dan Perindang Jalan, 15 Desember)

Hal tersebut dibenarkan melalui wawancara dengan Pak Supramana:

"Aturan dasar dalam kerjasama hanya kontrak kerja dan kesepakatan yang telah disepakati pada saat awal kontrak saja." (Supramana, Kepala CV Sarana Mega Konstruksi, 17 Februari 2021)

\section{b. Musyawarah dan Dialog}

Musyawarah dan dialog merupakan media untuk berdiskusi, menyampaikan aspirasi, sekaligus mencari solusi untuk menyelesaikan permasalahan yang mungkin terjadi selama pelaksanaan Collaborative Governance dan pengelolaan RTHP. Dalam proses pengelolaan RTHP di Kota Yogyakarta, musyawarah dengan masyarakat pertama kali dilaksanakan ketika pihak pengelola meninjau lahan RTHP yang akan dibangun. Pihak pengelola akan megundang berbagai tokoh masyarakat untuk menyampaikan usulan, masukan atau saran terkait pembangunan RTHP. Musyawarah ini yang akan menjadi patokan pihak pengelola untuk membuat rancangan pembangunan. Hal ini sesuai dengan yang dikatakan Ibu Rina, Kepala Seksi Pengelolaan RTHP: 
"Musyawarah dengan masyarat dilakukan untuk pertama kali meninjau lahan dan mengundang tokoh masyarakat yang berada di daerah permukiman, kemudian di sana kita membuka peluang untuk masyarakat menyampaikan usulannya terkait gambaran RTHP yang akan di bangun."

Setelah rancangan pembangunan yang dibuat oleh pihak DLH Kota Yogyakarta selesai, maka dilakukan musyawarah dan dialog yang dihadiri oleh tokoh masyarakat yang telah usul di lapangan. Musyawarah yang dilakukan untuk mengetahui apakah masyarakat sepakat atau tidak dengan rancangan yang telah dibuat. Apabila sudah sepakat maka langsung dilakukan proses pembangunan. Setelah pembangunan selesai, musyawarah masih dilakukan untuk membahas bagaimana pengelolaan dan perawatan RTHP. Hal ini sesuai dengan yang disampaikan oleh masyarakat:

"Semua rancangan pembangunan sudah berasal dari pihak DLH, masyarakat akan usul apabila rancangan pembangunan ada yang tidak sesuai kebutuhan masyarakat di Kelurahan Kadipaten.” (Mohammad Suhadi Jamil, 14 Desember 2020)

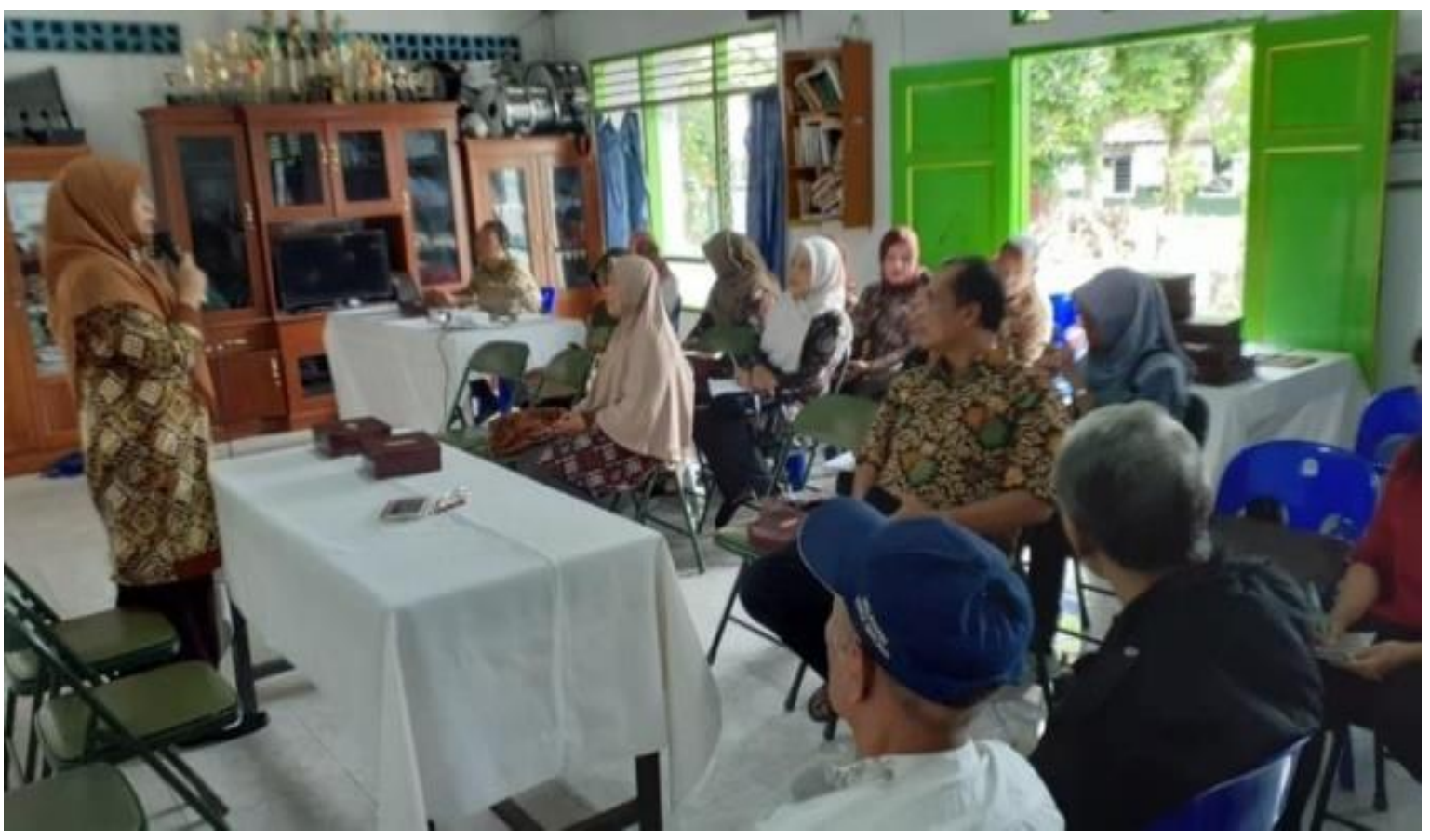

Gambar 4. Musyawarah dan Dialog dengan Masyarakat di Kelurahan Kadipaten Sumber: Dinas Lingkungan Hidup Kota Yogyakarta

Sama halnya dengan daerah permukiman, musyawarah dan dialog juga dilakukan antara UPT Malioboro dan BLH atau UPT Malioboro dengan paguyuban kawasan Malioboro atau bahkan dengan segenap Stakeholder yang terlibat dalam kerjasama kawasan Malioboro. Namun, berbeda dengan masyarakat di permukiman dan pengelolaan Malioboro, dimana antara pihak DLH dan CV Sarana Mega Konstruksi tidak melakukan musyawarah, dikarenakan CV Sarana Mega Konstruksi hanya menjalankan tugas yang sudah disepakati pada awal kontak kerja dengan pihak DLH. Jadi selama proses kerja mereka hanya melakukan komunikasi terkait tugas yang harus dilaksanakan.

\section{c. Mencapai Kesepakatan Kolaboratif}


Kesepakatan kolaboratif adalah kesepakatan bersama pemangku kepentingan yang diambil ketika dilakukannya musyawarah dan dialog dengan mempertimbangkan tiap ide yang dikeluarkan oleh masing-masing pemangku kepentingan sehingga menghasilkan suatu kesepakatan bersama. Kesepakatan inilah yang digunakan sebagai solusi untuk menyelesaikan permasalahan dan sebagai acuan kerja setiap Stakeholder dalam menjalankan Collaborative Governance. Dalam proses pengelolaan RTHP Kota Yogyakarta, pihak DLH yang paling mendominasi dan melaksanakan proses pengelolaan RTHP dengan alur yang tidak berubah. Hal ini dikarenakan pihak pemerintah menjalankan tugas sesuai dengan Perwal Yogyakarta dan pemangku kepentingan lainnya telah mendapatkan tugasnya masing-masing. Meskipun demikian, masyarakat tetap diberikan kesempatan untuk memberikan saran, masukan, ide, inovasi dll, melalui musyawarah dan dialog. Seperti beberapa pernyataan berikut:

"Masyarakat lebih banyak mendominasi dalam memberikan usulan pada saat musyawarah dan dialog dilakukan dan kemudian mendapatkan kesepakatan kolaboratif sebagai solusi dari permasalahan." (Rina Aryati Nugraha, Kepala Seksi Pengelolaan RTHP, 14 Desember 2020)

Hal ini dibenarkan oleh salah satu masyarakat:

"Hasil akhir dari jalannya musyawarah disepakati bersama baik dengan pihak DLH maupun tokoh masyarakat." (Mohammad Suhadi Jamil, Ketua RT 12 Kelurahan Kadipaten, 14 Desember 2020)

Mencapai kesepakatan kolaboratif juga dilakukan oleh UST Kota Yogyakarta dengan DLH Kota Yogyakarta untuk menyepakati lingkungan mana saja yang akan menjadi target mereka membersihkan area sempadan sungai. Melalui dialog yang dilakukan, maka akan diperoleh kesepakatan bersama untuk mencapai tujuan bersama. Sedangkan Pihak CV Sarana Konstruksi yang menjalin kontrak dengan DLH Kota Yogyakarta melakukan kesepakatan di awal kontrak kerja. Selain pembagian wilayah, kedua belah pihak juga sepakat dengan biaya untuk kontrak dalam satu tahun.

\section{Tahapan Implementation}

Tahapan ini untuk menjalankan kesepakatan yang telah disetujui pada tahapan yang telah dilaksanakan sebelumnya. Ada beberapa indikator dalam tahapan implementasi, yaitu:

\section{a. Adanya Pembagian Tugas}

Pembagian tugas dihasilkan dari tahapan-tahapan sebelumnya yang telah disetujui oleh para pemangku kepentingan yang kemudian tugas ini menjadi tanggungjawab dari masingmasing pemangku kepentingan. Pada tahapan implementasi ini berguna untuk mengetahui bagaimana pembagian tugas untuk setiap pemangku kepentingan dalam menjalankan Collaborative Governance. Pembagian tugas bagi pemerintah dan masyarakat diatur dalam aturan dasar yang termuat dalam Perwal Yogyakarta No. 5 Tahun 2016. Dalam aturan dasar tersebut terdapat tugas pemerintah sebagai penyedia dan pemelihara dengan dibantu oleh masyarakat dalam pemeliharaan RTHP. Hal ini sesuai dengan yang disampaikan oleh Ibu Rina, Kepala Seksi Pengelolaan RTHP (14, Desember 2020): 
"Pembagian tugas untuk pihak pemerintah dan masyarakat tersebut bukan berasal dari kesepakatan bersama, melainkan sudah ditetapkan oleh pemerintah yang terdapat pada aturan dasar yaitu Perwal Yogyakarta No 5 Tahun 2016."

Dibernarkan oleh masyarakat:

"Baik pihak DLH maupun masyarakat sekitar bersama-sama untuk memelihara hadirnya RTHP Taman Flamboyan yang memiliki banyak fungsi selain fungsi sosial untuk bermain anak-anak dan area olahraga juga memiliki fungsi segi ekonomi bagi masyarakat yang berjualan di sekitar RTHP Taman Flamboyan." (Slamet Widayat, Ketua RT 07 Kelurahan Kricak, 7 Januari 2021)

Pembagian tugas juga dilakukan kepada UST Kota Yogyakarta sebagai pihak yang juga memberikan bantuan pada pengelolaan RTHP Kota Yogyakarta, dimana pihak UST merupakan pihak utama yang melakukan pembersihan lingkungan sempadan sungai dan dibantu oleh DLH Kota Yogyakarta serta masyarakat sekitar. Sedangkan UPT Malioboro dan LPKKM yang bertanggungjawab pada pengelolaan RTHP di kawasan Malioboro bertugas mengumpulkan dan menampung aspirasi masyarakat melalui paguyuban yang dibentuk. Pihak swasta di sekitas kawasan Malioboro seperti pemilik usaha, toko, hotel, dan mall serta masyarakat juga diwajibkan untuk bersama-sama menjaga, merawat dan membersihkan RTHP di sekitar tempat tinggal atau wilayah mereka, agar kerapihan, kebersihan dan kenyamanan RTHP tetap terjaga.

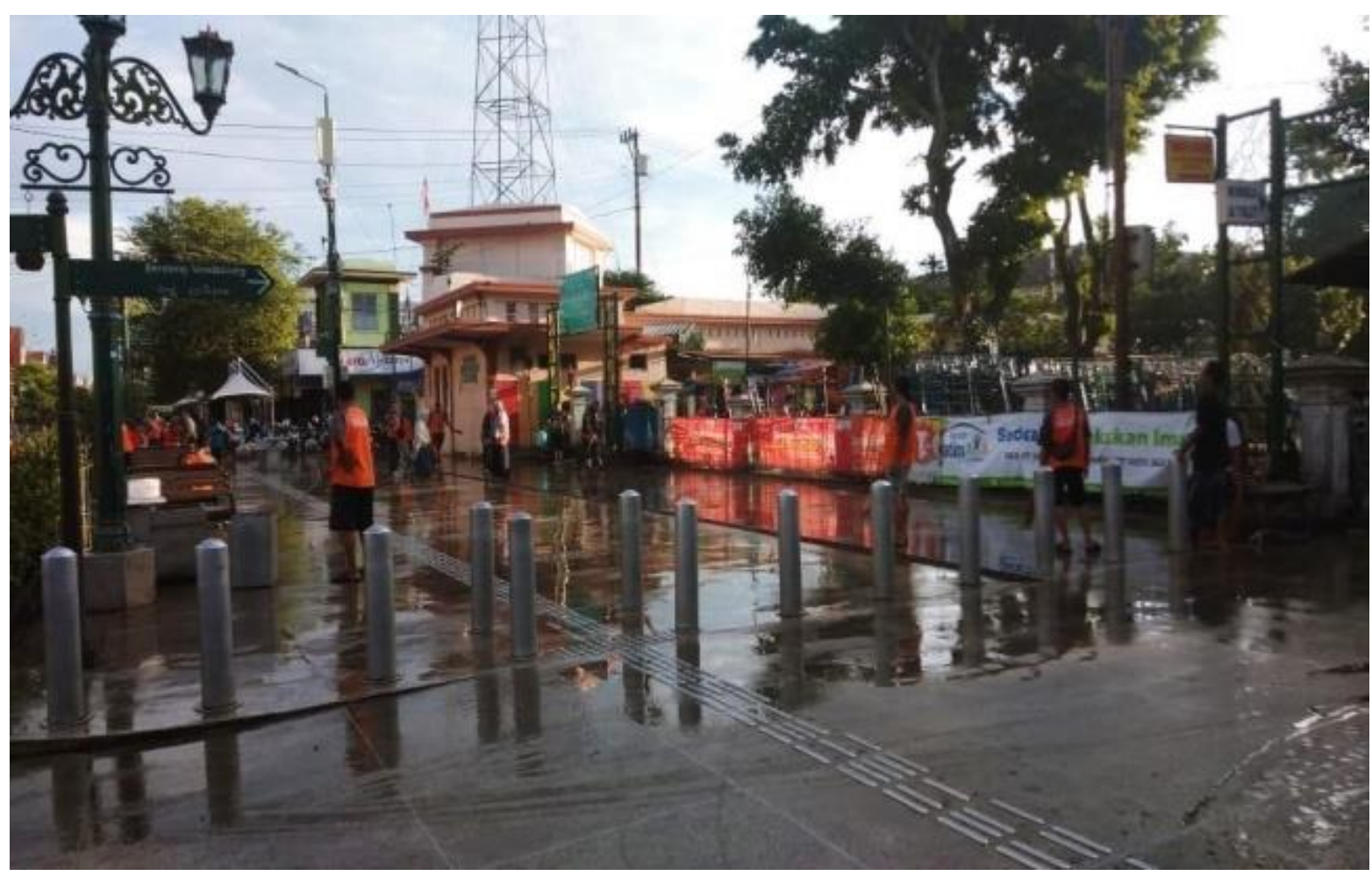

Gambar 5. DLH dan PKL Malioboro Melakukan Bersih-Bersih Kawasan Malioboro Sumber: Dinas Lingkungan Hidup Kota Yogyakarta

Pihak swasta yang juga bekerja sama dengan DLH Kota Yoygyakarta yaitu CV Sarana 
Mega Konstruksi bertugas sebagai kontraktor yang melakukan pemeliharaan terhadap RTHP seperti penebangan pohon. Hal ini sesuai dengan pernyataan dari Bapak Supramana, Kepala CV Sarana Mega Konstruksi (17 februari 2021:

"CV Sarana Mega Konstruksi melakukan pengerjaan sebagai kontraktor yang bertugas untuk membantu dalam pemangkasan pohon kurang lebih sekitar 5000 pohon yang tersebar di ruas jalanan Kota Yogyakarta. Pekerjaan ini dilakukan sesuai dengan kontrak tahunan dan pengerjaan dilakukan dengan memulai dari jalan yang sepi dahulu untuk mengejar target."

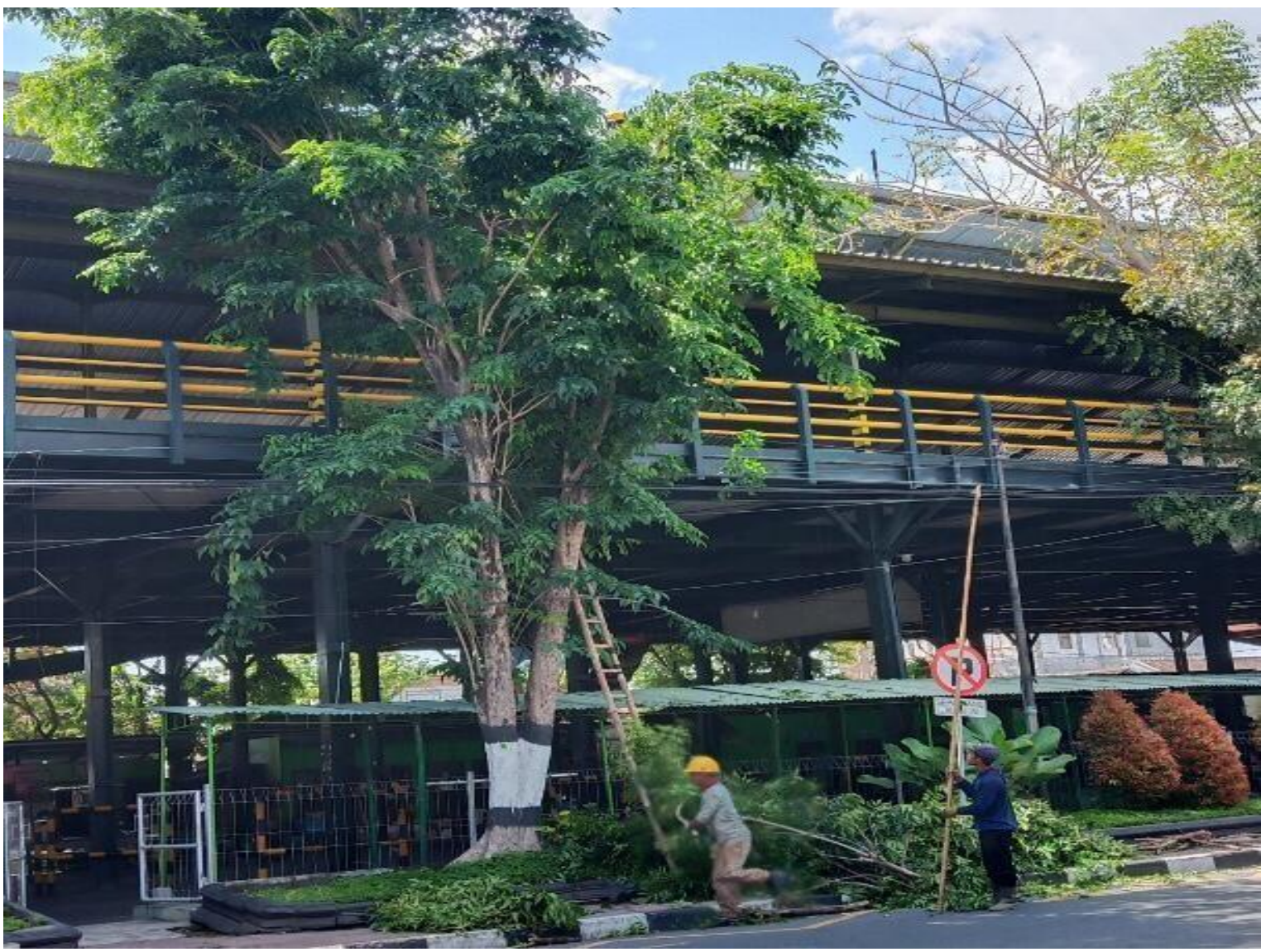

Gambar 6. CV Sarana Mega Konstruksi Menjalankan Tugas Pemangkasan Pohon Sumber: Dinas Lingkungan Hidup Kota Yogyakarta

Dengan adanya penjelasan diatas, bisa diketahui tiap-tiap pemangku kepentingan sudah memliki tugas dan tanggungjawabnya masing-masing. Akan tetapi tugas tersebut didapat bukan dari hasil yang disetujui bersama, melainkan dari Peraturan Walikota untuk pihak pemerintah dan masyarakat dan dari DLH Kota Yogayakarta untuk pihak swasta.

\section{b. Mengevaluasi Hasil}

Evaluasi hasil adalah proses untuk mengetahui apakah kegiatan tersebut mencapai tujuan yang sudah direncanakan atau tidak. Evaluasi hasil dilakukan pada akhir kegiatan dan dapat juga membantu dalam menyelesaikan masalah apabila dalam evaluasi hasil tersebut ternyata 
belum mencapai tingkat keberhasilan. Pada proses pengelolaan RTHP sebelum melakukan evaluasi maka dilakukan adanya monitoring terlebih dahulu yang dilakukan langsung oleh pihak DLH Kota Yogyakarta. Pihak DLH memiliki staff lapangan yang bertugas sebagai pengawas yang akan datang untuk memonitoring pemeliharaan RTHP.

"Selain dari pihak DLH yang mengirimkan pengawas untuk melakukan monitoring seminggu sekali adapula pengawas dari Dinas Tata Ruang dan Dinas Pertanahan yang bertugas untuk memonitoring apakah RTHP masih berjalan aktif atau tidak, monitoring yang dilakukan oleh instansi lain dilakukan sebulan sekali." (Rina Aryati Nugraha, Kepala Seksi Pengelolaan RTHP, 14 Desember 2020)

Evaluasi hasil dalam pengelolaan RTHP tidak dijalankan secara terjadwal, namun dilakukan apabila masyarakat menginginkan adanya sebuah pertemuan. Masyarakat lebih sering memberikan solusi atau pengajuan permintaan kepada staff dari DLH Kota Yogyakarta secara langsung saat staff tersebut sedang bekerja untuk membersihkan RTHP setempat. Selain ke staff lapangan yang bertugas sebagai kebersihan RTHP, masyarakat juga mengajukan usul kepada staff yang bertugas sebagai pengawas. Hal ini dibenarkan dari hasil wawancara dengan masyarakat:

"Masyarakat melakukan usulan biasanya secara langsung kepada staff yang sedang berjaga atau melalui aplikasi Jogja Smart Service (JSS) atau biasanya juga langsung melalui WhatsApp." (Mohammad Suhadi Jamil, Ketua RT 12 Kelurahan Kadipaten, 14 Desember 2020)

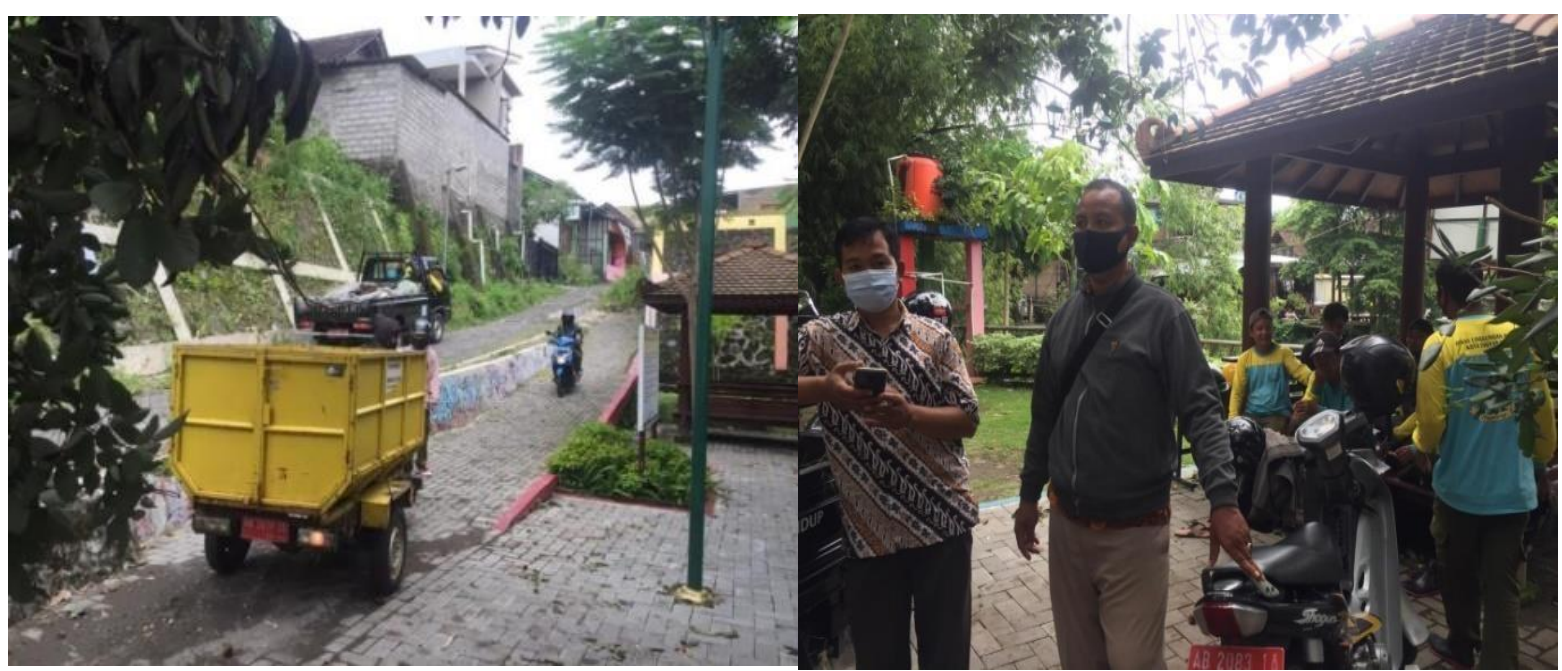

Gambar 7. CV Sarana Mega Konstruksi Menjalankan Tugas Pemangkasan Pohon

Evaluasi dalam pengelolaan kawasan Malioboro dilakukan dengan seluruh Stakeholder untuk mengetahui kendala apa saja yang terjadi selama program kerja berlangsung. Melalui evaluasi ini maka akan diketahui apa saja kendala atau target yang belum tercapai dan bagaimana menyelesaikan masalah tersebut. Masyarakat atau paguyuban lebih sering untuk mengajukan aspirasi kepada UPT Malioboro, hal ini karena UPT Malioboro lebih informatif dalam menyampaikan hal-hal terkait pegelolaan kawasan Malioboro. Sedangkan evaluasi yang 
dilakukan antara DLH dengan pihak swasta hampir tidak pernah dilakukan, karena pada saat kontrak di tahun kedua yaitu 2020 antara DLH dan CV Sarana Mega Konstruksi sudah tidak melakukan evaluasi, CV Sarana Mega Konstruksi hanya melakukan komunikasi dengan pihak DLH Kota Yogyakarta saja dan fokus dengan mengejar target kerja yang sudah disepakati bersama dengan pihak DLH Kota Yogyakarta. Hal ini sesuai dengan hasil wawancara dengan Bapak Supramana:

"Evaluasi dilakukan hanya pada saat satu tahun pertama kontrak kerja yaitu ditahun 2019 dan dilakukan secara berkala, yaitu sekali setiap minggu, namun setelah kontrak kedua di tahun 2020 tidak pernah lagi." (Supramana, Kepala CV Sarana Mega Konstruksi, 17 Februari 2021)

Berdasarkan dari beberapa tahapan yang sudah dijalankan dalam proses collaborative govenance yang dijabarkan oleh Ricardo S. Morse dan John B. Stephens, secara keseluruhan proses yang sudah dilalui sudah cukup baik dalam menjalankan Collaborative Governance dalam pengelolaan RTHP Kota Yogyakarta, namun masih ada beberapa indikator yang belum sepenuhnya dijalankan contohnya seperti pembuatan SOP yang belum masif dihadirkan, musyawarah dan evaluasi yang tidak pernah dilakukan antara pihak pemerintah yaitu DLH dan pihak swasta yaitu CV Sarana Mega Konstruksi yang menurut peneliti itu penting untuk dilakukan untuk mengetahui kinerja yang sudah dikerjakan. Hal ini terjadi karena sistem kerja yang dijalankan masih bersifat komando dari pemerintah, sehingga pihak swasta hanya menjalankan yang sudah menjadi ketentuan pemerintah.

\section{KESIMPULAN DAN SARAN}

Dalam collaborative governance terdapat beberapa tahapan, yaitu assesment, initiation, deliberation, implementation, masing-masing dapat disimpulkan bahwa tahapan Assesment memiliki tiga indikator yang dimana ketiganya berjalan dengan baik, karena pada tahap ini merupakan tahapan penilaian untuk menentukan apakah sebuah kerjasama diperlukan dan untuk menentukan siapa saja yang akan diajak untuk bekerjasama. Pada tahapan ini diketahui bahwa sebuah kerjasama dengan beberapa stakeholder, yaitu dengan mengajak pihak swasta dan masyarakat. Pada tahapan Initiation terdapat tiga indikator, dua diantaranya sudah berjalan baik yaitu menentukan sumber daya dan mempertemukan pemangku kepentingan, namun pada indikator ketiga yaitu mendesign proses yang dimana hasil akhirnya adalah SOP akan tetapi pembuatan SOP ini tidak diadakan dalam menjalin kerjasama antara DLH dan CV Sarana Megra Konstruksi.

Tahapan Deliberation ada tahap ini memiliki tiga indikator, pada indikator pertama yaitu membangun aturan dasar yang dimana aturan dasar sudah diatur dalam Perwal Yogyakarta Nomor 5 Tahun 2016 yang hanya berlaku untuk pihak DLH dan masyarakat, sedangkan pihak swasta hanya mengikuti peraturan yang sudah ditetapkan oleh pihak DLH Kota Yogyakarta. Aturan dasar untuk pengelolaan kawasan Malioboro sudah diatur dalam Peraturan Walikota Nomor 8 Tahun 2012. Pada indikator kedua yaitu musyawarah dan dialog yang dijalankan oleh pihak DLH dan masyarakat serta antar stakeholder di kawasan Malioboro sudah dijalankan dengan baik akan tetapi antara pemerintah dan swasta tidak pernah dilakukan musyawarah, karena pihak swasta hanya menjalankan kerja sesuai kontrak kerja. Selanjutnya pada indikator 
mencapai kesepakatan kolaboratif sudah berjalan dengan baik, seluruh pemangku kepentingan dapat menyepakati hasil akhir karena semuanya memiliki kedudukan yang sama dalam menjalankan kerjasama.

Tahapan Implementation, pada tahapan ini memiliki dua indikator, pada indikator pertama adanya pembagian tugas, pembagian tugas antara pemerintah dan masyarakat sudah diatur dalam Perwal Yogyakarta Nomor 5 Tahun 2016, dimana pemerintah sebagai pihak penyedia dan masyarakat membantu dalam pemeliharaan RTHP, dan dalam pengelolaan kawasan Malioboro sudah dibagikan tugas yang sesuai dengan Peraturan Walikota Nomor 8 Tahun 2012 sedangkan tugas pihak swasta ditetapkan oleh DLH Kota Yogyakarta. Pada indikator kedua yaitu mengevaluasi hasil, dimana sebelum evaluasi, pemerintah akan melakukan monitoring yang dilakukan oleh staff dari pihak DLH kota Yogyakarta guna mengetahui bagaimana pengelolaan RTHP. Proses evaluasi dilakukan secara tidak terjadwal namun tetap akan dilaksanakan apabila dari pihak masyarakat ingin melakukan pertemuan guna menyampaikan usulan kepada pihak DLH dalam pengelolaan RTHP. Untuk pihak swasta tidak pernah dilakukan evaluasi karena pihak swasta hanya melakukan pekerjaan yang sudah disepakati diawal dengan pihak DLH.

Saran peneliti adalah pihak DLH Kota Yogyakarta tetap harus menyediakan dan menambah RTHP di Kota Yogyakarta karena RTHP di Kota Yogyakarta belum mencapai 20\% dari luasan wilayah kota. Pihak DLH Kota Yogyakarta perlu inisiatif untuk pembuatan SOP dalam kerjasama pengelolaan RTHP dengan semua stakeholder. Setiap pemangku juga harus aktif dalam memberikan usulan atau ide untuk pihak DLH Kota Yogyakarta dan untuk pengelolaan RTHP yang harus dilakukan dengan semua pemangku kepentingan seperti diadakannya musyawarah dan dialog untuk mencapai kesepakatan kolaboratif. DLH Kota Yogyakarta sebagai pihak penyedia serta pengelola harus memfasilitasi pertemuan antar stakeholder terutama evaluasi yang harus dilakukan secara berkala dengan semua stakeholder untuk mengetahui apa saja kendala yang terjadi di lapangan untuk pengelolaan RTHP. Pengelolaan RTHP terutama pemeliharaan sudah menjadi kewajiban kita semua untuk menjaganya agar Kota Yogyakarta yang menjadi salah satu kota destinasi pariwisata menjadi lebih asri dan indah dipandang oleh mata.

\section{DAFTAR PUSTAKA}

Amelia, N. A. (2018). Collaborative Governance dan Pengelolaan Lingkungan Hidup di Kawasan Pertambangan. Jurnal Ilmiah Administrasi Publik, 4(1), 27-35.

Andhini, N. F. (2017). Evaluasi Program Pengelolaan Ruang Terbuka Hijau Dinas Lingkungan Hidup Kota Yogyakarta. Journal of Chemical Information and Modeling, 53(9), 16891699.

Andriani, A. (2019). Collaborative Governance Dalam Pembangunan Ruang Terbuka Hijau Tanjung Bersinar Parkdi Kabupaten Tabalong. Doctoral Dissertation, University of Muhammadiyah Malang, 24, 1-23.

Ansell, C., \& Gash, A. (2007). Collaborative Governance In Theory and Practice. Journal of Public Administration Research and Theory. 18(4), 543-571

Arianti, D., \& Satlisa, L. (2018). Collaborative Governance Dalam Pengembangan Konservasi Mangrove Baros di Desa Tirtohargo Kecamatan Kretek Kabupaten Bantul. Jurnal Natapraja, 7(1), 2406-9515. 
Astriani, N. (2015). Peran Serta Masyarakat Dalam Pengelolaan Ruang Terbuka Hijau (RTH) Di Kota Bandung. Veritas et Justitia, 1(2), 274-297.

BPS, (Badan Pusat Statistik). (2020). Kota Yogyakarta dalam Angka.

Budiman, A., Sulistyantara, B., \& Zain FM, A. (2014). Deteksi Perubahan Ruang Terbuka Hijau Pada 5 Kota Besar Di Pulau Jawa (Studi Kasus: Dki Jakarta, Kota Bandung, Kota Semarang, Kota Jogjakarta, Dan Kota Surabaya). Jurnal Lanskap Indonesia, 6(1), 7-15.

Dinas Lingkungan Hidup Kota Yogyakarta. (2017). Buku Profil Dinas Lingkungan Hidup Kota Yogyakarta.

Duadji, N., \& Tresiana, N. (2018). Kota Layak Anak Berbasis Collaborative Governance. Sawwa: Jurnal Studi Gender, 13(1).

Hariyono, P. (2017). Perencanaan Pembangunan Kota dan Perubahan Paradigma (2nd ed). Pustaka Pelajar.

Haryanto, P. (2019). Ruang Terbuka Hijau.

Jamaludin, A. N. (2015). Sosiologi Perkotaan. In Sosiologi Perkotaan, 2.

Morse, R. S., \& Stephen, J. B. (2012). Teaching Collaborative Governance: Phases, Competencies, and Case-Based Learning. Journal of Public Affairs Education, 18(3), $565-583$.

Parameshwari, A., Okta, D., Fajrina, M., Amsyah, E., \& Malang, U. M. (2020). Collaborative Governance dalam Manajemen Tata Ruang di Cafe Sawah Pujon Kidul. Prosiding Simposium Nasional "Tantangan Penyelenggaraan Pemerintahan Di Era Revolusi Indusri 4. $0, " 1046-1070$.

Rosawatiningsih, N. (2019). Kebijakan Pengelolaan Ruang Terbuka Hijau (RTH) Taman Flora Surabaya. The Journal of Society \& Media, 3(1), 68.

Sudaryono. (2017). Metodologi Penelitian (1st ed). PT Rajagrafindo Persada.

Tresiana, N., \& Duadji, N. (2017). Kolaboratif Pengelolaan Pariwisata Teluk Kilauan (Collaborative Management Of The Teluk Kiluan Tourism). Seminar Nasional FISIP Unila, 77-84.

Ulfa, L. M. (2018). Collaborative Governance dalam Penyediaan Ruang Terbuka Hijau (RTH) Taman Kota di Surabaya. Doctoral Dissertation, Universitas Airlangga.

Yusuf, M. (2014). Metode Penelitian: Kuantitatif, Kualitatif, dan Penelitian Gabungan (1st ed). Kencana. 